\title{
Deciphering tectonic phases of the Amundsen Sea Embayment shelf, West Antarctica, from a magnetic anomaly grid
}

\author{
Karsten Gohl ${ }^{\text {a, } *}$, Astrid Denk ${ }^{\mathrm{a}, \mathrm{b}, 1}$, Graeme Eagles $^{\mathrm{c}}$, Florian Wobbe ${ }^{\mathrm{a}}$ \\ a Alfred Wegener Institute for Polar and Marine Research, Am Alten Hafen 26, Bremerhaven 27568, Germany \\ ${ }^{\mathrm{b}}$ Institute of Geophysics and Meteorology, University of Cologne, Zülpicher Straße 49a, Köln 50674, Germany \\ c Dept. of Earth Sciences, Royal Holloway University of London, Egham TW20 OEX, UK
}

\section{A R T I C L E I N F O}

\section{Article history:}

Received 7 September 2011

Received in revised form 15 May 2012

Accepted 20 June 2012

Available online 2 July 2012

\section{Keywords:}

Aeromagnetics

Data processing

Pine Island Bay

Gondwana breakup

Bellingshausen Plate

West Antarctic Rift System

\begin{abstract}
A B S T R A C T
The Amundsen Sea Embayment (ASE), with Pine Island Bay (PIB) in the eastern embayment, is a key location to understanding tectonic processes of the Pacific margin of West Antarctica. PIB has for a long time been suggested to contain the crustal boundary between the Thurston Island block and the Marie Byrd Land block. Plate tectonic reconstructions have shown that the initial rifting and breakup of New Zealand from West Antarctica occurred between Chatham Rise and the eastern Marie Byrd Land at the ASE. Recent concepts have discussed the possibility of PIB being the site of one of the eastern branches of the West Antarctic Rift System (WARS). About 30,000 km of aeromagnetic data - collected opportunistically by ship-based helicopter flights - and tracks of ship-borne magnetics were recorded over the ASE shelf during two RV Polarstern expeditions in 2006 and 2010. Grid processing, Euler deconvolution and 2D modelling were applied for the analysis of magnetic anomaly patterns, identification of structural lineaments and characterisation of magnetic source bodies. The grid clearly outlines the boundary zone between the inner shelf with outcropping basement rocks and the sedimentary basins of the middle to outer shelf. Distinct zones of anomaly patterns and lineaments can be associated with at least three tectonic phases from (1) magmatic emplacement zones of Cretaceous rifting and breakup (100-85 Ma), to (2) a southern distributed plate boundary zone of the Bellingshausen Plate (80-61 Ma) and (3) activities of the WARS indicated by NNESSW trending lineaments (55-30 Ma?). The analysis and interpretation are also used for constraining the directions of some of the flow paths of past grounded ice streams across the shelf.
\end{abstract}

(C) 2012 Elsevier B.V. All rights reserved.

\section{Introduction}

The Amundsen Sea Embayment contains one of the largest continental shelves of the Pacific margin of West Antarctica. Pine Island Bay, in the eastern part of the embayment, has for a long time been suggested to contain the crustal boundary between the Thurston Island block and the Marie Byrd Land block (e.g. Dalziel and Elliot, 1982; Grunow et al., 1991; Storey, 1991). Plate tectonic reconstructions suggest that this region was a key area for the initiation of continental breakup, that it was the location of a possible plate boundary, and that it may have been, or still is, an active branch of the West Antarctic Rift System (Dalziel, 2006; Eagles et al., 2004a; Gohl et al., 2007;

\footnotetext{
* Corresponding author at: Dept. of Geosciences, Alfred Wegener Institute for Polar and Marine Research, Am Alten Hafen 26, Bremerhaven 27568, Germany. Tel.: + 49 47148311361 ; fax: + 4947148311271.

E-mail addresses: karsten.gohl@awi.de (K. Gohl), astrid.denk@ifg.uni-tuebingen.de (A. Denk), g.eagles@gl.rhul.ac.uk (G. Eagles), florian.wobbe@awi.de (F. Wobbe).

${ }^{1}$ Present address: Dept. of Geosciences, University of Tübingen, Hölderlinstr. 12, Tübingen 72074, Germany.
}

Jordan et al., 2010; Larter et al., 2002; Wobbe et al., 2012). In spite of all this, little is known about the tectonic evolution and architecture of the embayment from direct study there.

Tectonically induced displacements of the crust are the underlying processes controlling the development of landscapes upon which climate processes play out. This context is of particular importance for reconstructing continental ice sheet evolution. In the Amundsen Sea Embayment, the Pine Island, Thwaites, Smith and Kohler glacier systems are thinning at rapid rates, and some of them have also started to flow at dramatically increased rates (e.g. Rignot et al., 2008; Pritchard et al., 2009). If these glaciers were to drain their catchment area, the volume of ice lost to the ocean could potentially lead to $1.5 \mathrm{~m}$ of sea-level rise (Vaughan et al., 2006). Modelling results (Pollard and DeConto, 2009) suggest that the ice sheet in the Amundsen Sea Embayment may have retreated with similar dynamics several times since the Pliocene. Identifying tectonic lineaments and understanding the tectonic architecture of the shelf of the Amundsen Sea Embayment may thus not only help explaining the geodynamic and kinematic processes of continental rifting in this West Antarctic realm, but also provide valuable constraints on flow paths and subglacial substrate of basement for palaeo-ice sheet modellers. 
An extensive ship-borne and helicopter-borne magnetic dataset was collected for the first time in the Amundsen Sea Embayment and Pine Island Bay by the Alfred Wegener Institute during RV Polarstern expeditions ANT-XXIII/4 in 2006 and ANT-XXVI/3 in 2010. The distribution and spacing of the survey tracks are suitable to allow spatial gridding and 3D field analysis for delineating crustal and basement features. In this paper, we describe the workflow from magnetic data acquisition to processing and modelling and put forward a model for the tectonic architecture of the offshore Amundsen Sea Embayment.

\section{Geological and geophysical background}

Fig. 2 summarizes the main stages in the tectonic development of the Pacific margin of West Antarctica. At least three distinct phases since Late Cretaceous have been discussed in recent literature.

The extension, and subsequent separation, of New Zealand and West Antarctica dominate the tectonic signature of the Amundsen Sea Embayment. This early divergence of the Pacific and Antarctic plates led first to rifting and crustal extension between Chatham Rise and the Amundsen Sea Embayment off easternmost Marie Byrd Land as early as $90 \mathrm{Ma}$ (Eagles et al., 2004a; Larter et al., 2002; Wobbe et al., 2012). Rifting possibly continued within the Great South Basin between the Campbell Plateau and the South Island of New Zealand until its abandonment in favour of a new extensional locus to the south, forming the earliest oceanic crust between Campbell Plateau and Marie Byrd Land by $84-83$ Ma.

From about $79 \mathrm{Ma}$, the Bellingshausen Plate moved independently of the Pacific and Antarctic Ridge on the southern flank of the PacificAntarctic Ridge until about $61 \mathrm{Ma}$, when a major plate reorganisation occurred in the South Pacific (e.g. Eagles et al., 2004a,b; Larter et al., 2002). This small plate's western boundary passed through the region of the Marie Byrd Seamounts, north of the Amundsen Sea Embayment. Its eastern transpressional boundary lies along the Bellingshausen Gravity Anomaly lineament in the western Bellingshausen Sea (Eagles et al., 2004a; Gohl et al., 1997). Although a discrete southern plate boundary has been depicted running from the seamounts onto the shelf and mainland, its true nature is poorly known (Eagles et al., 2004a,b) and it may be a more distributed feature.

The location of Pine Island Bay has led several researchers to suggest that it hosts a major crustal boundary between the Marie Byrd Land block to the west and the Thurston Island/Ellsworth Land blocks to the east. These blocks are suggested to have moved with respect to each other during the Late Cretaceous New Zealand-Antarctic separation and perhaps also in early Mesozoic or Palaeozoic times (e.g. Dalziel and Elliot, 1982; Grunow et al., 1991; Storey, 1991). However, direct evidence of the presence of such a boundary is still missing. Conceptual models also suggest that Pine Island Bay and the eastern Amundsen Sea Embayment hosted basins of the West Antarctic Rift System. Jordan et al. (2010) invert airborne gravity data to reveal an extremely thin crust and low lithospheric rigidity beneath the onshore Pine Island Rift. Müller et al. (2007) and Eagles et al. (2009) considered how, at times between chrons 21 and 8 (48-26 Ma), the West Antarctic Rift System east of the Ross Sea operated in either dextral strike-slip or extensional motion through the region to the south and east of the Amundsen Sea Embayment connecting eventually to a Pacific-PhoenixEast Antarctic triple junction via the Byrd Subglacial Basin and the Bentley Subglacial Trench. There are indications for an early West Antarctic Rift System extension in western Marie Byrd Land in the mid-Cretaceous (e.g. McFadden et al., 2010), but its eastern continuation is less well understood. It is possible that in the north-south striking zone of thinned crust in Pine Island Bay was an eastern arm of this early manifestation of the West Antarctic Rift System (Dalziel, 2006; Ferraccioli et al., 2007; Gohl et al., 2007; Jordan et al., 2010).

\section{Magnetic surveys and data processing}

The Amundsen Sea was the target area for geoscientific, oceanographic and biological studies during the RV Polarstern expeditions ANT-XXIII/4 in 2006 and ANT-XXVI/3 in 2010. Ship-borne magnetic data were continuously recorded with two 3-component fluxgate magnetometer sensors, which are permanently installed on the crow's nest. One of the two BO-105 helicopters on board was equipped with a caesium-vapour magnetometer sensor towed by a

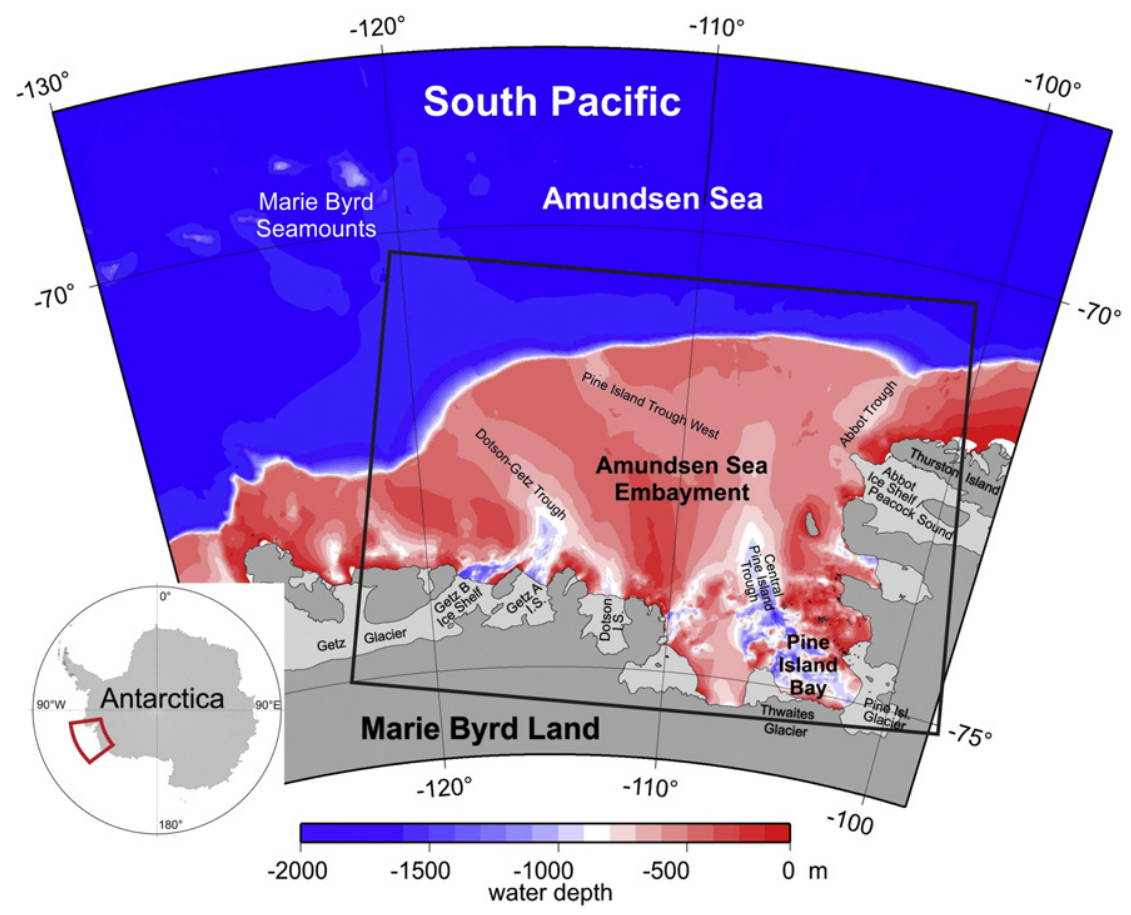

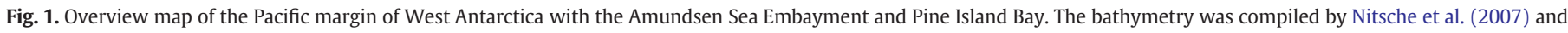

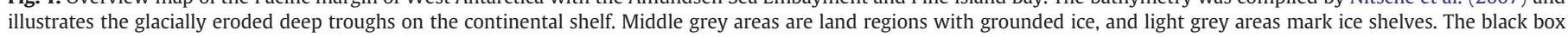
marks the area of the magnetic survey shown and discussed in this paper. 


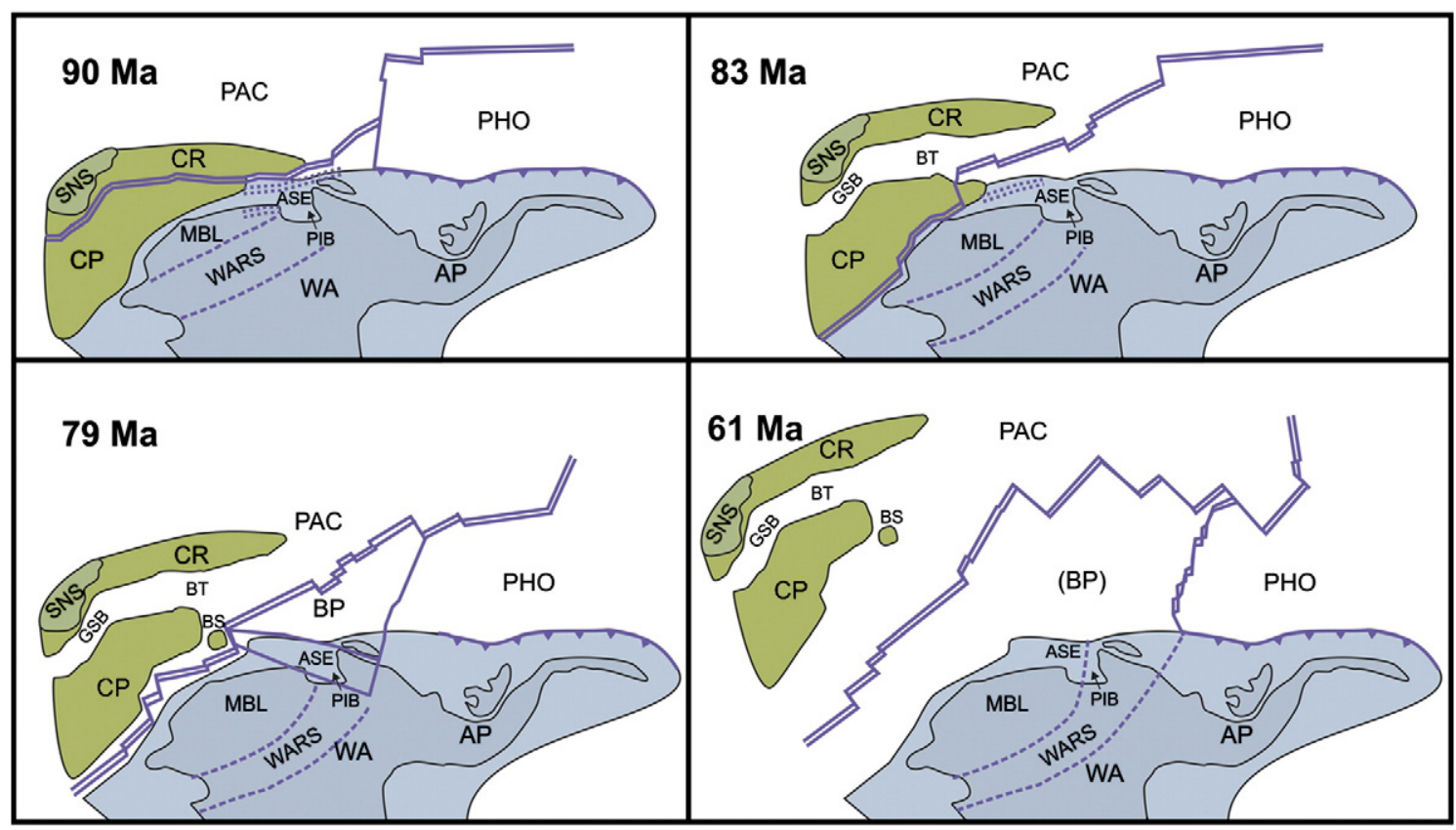

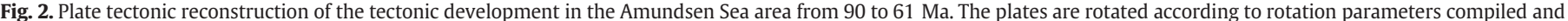

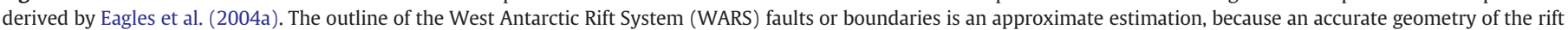

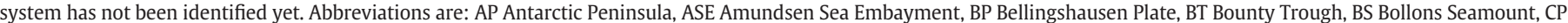

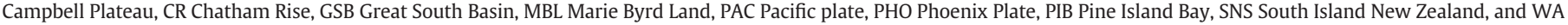
West Antarctica.

Modified from Gohl (2011).

$30 \mathrm{~m}$ long cable. Helicopter-borne magnetic data were collected opportunistically along track lines as far as possible within a predetermined survey pattern, but subject to the constraints of the vessel's primary marine geoscientific and oceanographic tasks. Each survey flight covered $350-450 \mathrm{~km}$ in 2 to $2.5 \mathrm{~h}$ at a nominal $100 \mathrm{~m}$ flight height with a sampling interval of 3-5 m. Up to 3 or 4 flights were conducted on days with good flight conditions and no other transport tasks. With this survey approach, the Amundsen Sea Embayment shelf was effectively covered with patches of survey lines that total about $30,000 \mathrm{~km}$ of data (Fig. 3). The survey line spacing

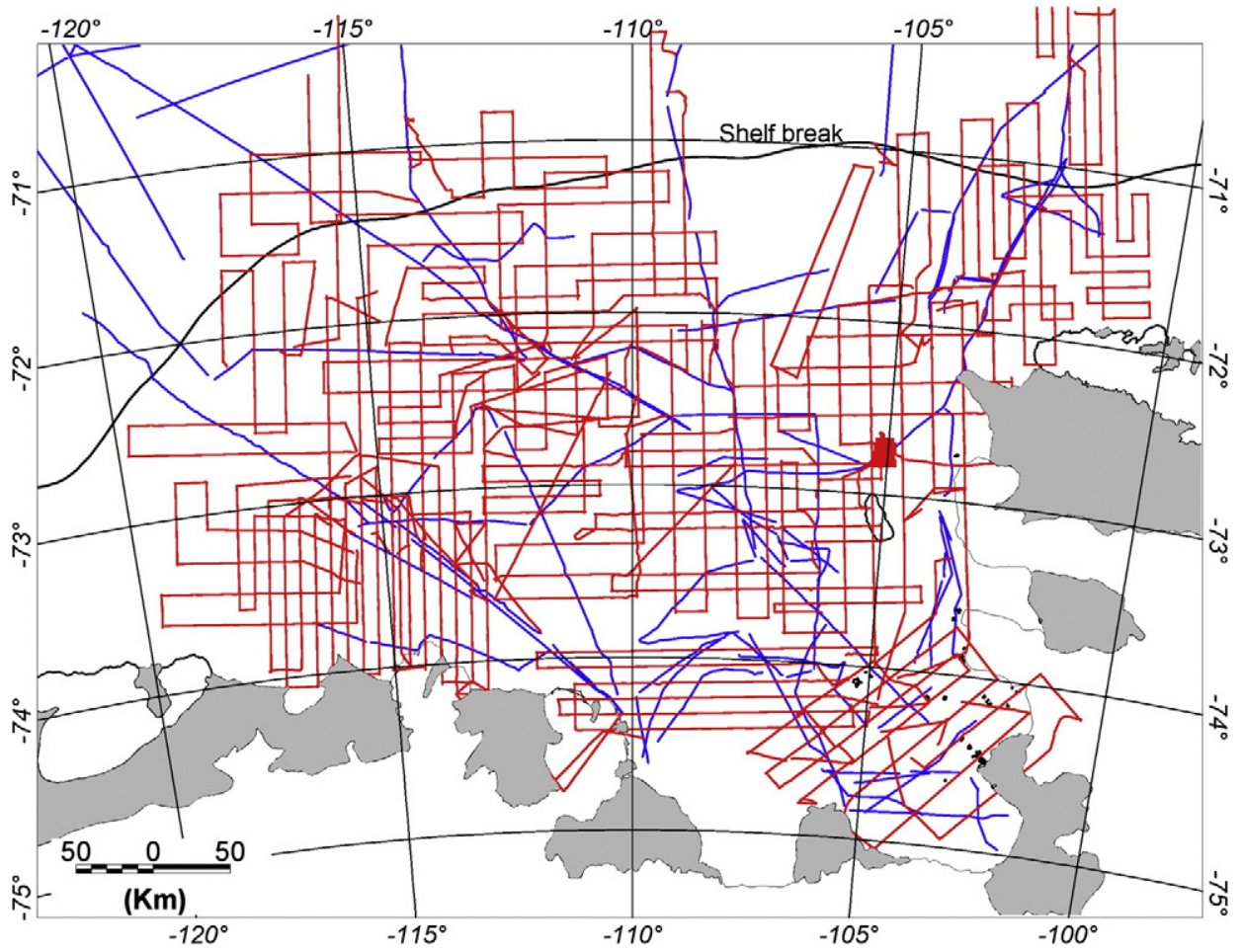

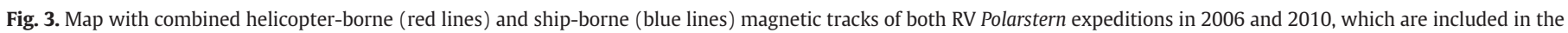
preparation of the magnetic anomaly grids. The irregular line geometry is due to opportunistic surveying. 
Table 1

Magnetic data processing and analysis flow.

Removal of IGRF

Editing and filtering

\section{$\downarrow$}

Upward field continuation of ship-borne data to $150 \mathrm{~m}$

Cross-point analysis and levelling

Gridding and micro-levelling

Derivatives, field continuations, high-pass filtering, analytical signal

Power spectra, Euler deconvolution

2-D forward modelling

varies between 5 and $25 \mathrm{~km}$ and - although a regular flight grid could not be maintained - allows spatial gridding and 3-D field analysis for delineating regional crustal and basement features.

Before merging into the processing stream with the helicoptermagnetic data, the 3-component ship-borne magnetic data had to be pre-processed to compensate for interactions between the ship's ferrous body and the variable geomagnetic field. To facilitate this, a number of figure-eight shaped magnetic compensation loops were completed during the cruises from which compensation coefficients for all headings were calculated. Corrections were applied using these coefficients according to the methods and descriptions of König (2006) and Wobbe et al. (2012). The main contribution to an erroneous shift of the measured magnetic data comes from the ship's heading (Nogi and Kaminuma, 1999). For instance, a one degree change of the ship's heading causes about $300 \mathrm{nT}$ of variation in the horizontal components. The vertical component is less affected by the ship's heading but shows noise due to roll and pitch. In order to avoid noise in the total intensity field, the data acquired during and immediately after substantial heading changes were excluded from further processing.

The total magnetic field data of helicopter-borne caesium-vapour sensor turned out to be rather unaffected by the helicopter's heading, except for major turns at flight line change. Such data were also removed from further processing. In general, the helicopter-magnetic records appeared to be less noisy than the ship-borne data.
After this initial pre-processing, both ship-borne and helicopter-borne data went through the same principal processing steps (Table 1) using Geosoft Oasis montaj ${ }^{T M}$ software for most applications:

Removal of International Geomagnetic Reference Field (IGRF): We removed the IGRFs of 2005 and 2010 from the data of 2006 and 2010 , respectively. We used the mean date for each survey.

Editing and filtering: Visual editing of obvious erroneous data improved the overall data quality of the datasets of both expeditions. For instance, data affected by tilts in loops of the helicopter's flight tracks were removed. Large numbers of data were removed in particular from the ship-borne records, owing to noise induced during ship manoeuvres, heading changes and crane movements. A band-pass filter removed spikes and other short-wavelength noise from all datasets. As it was not possible to set up a magnetic base station in the coastal area of the Amundsen Sea Embayment for the duration of both cruises, the data may still be affected by diurnal variations of the geomagnetic field.

Levelling: This process is required to the data in order to minimise the differences at cross-points before any gridding is applied. The plane tolerance of crossing survey line points was chosen to be $0.0005^{\circ}(\sim 50 \mathrm{~m})$. As the helicopter data have shown to provide more reliable results than the ship-borne data, the two datasets were treated separately. The differences at cross-points within the dataset were minimised using an iterative approach to their mean values. We divided the intersection points of the helicopter lines into reliable intersection points (differences vary less then \pm $10 \mathrm{nT}$ ) and less reliable intersections points (all other intersection points). In the first step, these lines were levelled separately: Lines with reliable intersection points were levelled using an 'iterative levelling' algorithm. Lines with less reliable intersections were levelled using 'full levelling' algorithm. 'Iterative levelling' calculates a least-squares trend line through the error data to derive a linear trend error curve, which is then added to the data to be levelled. These steps are repeated for crossing lines until a convergence is reached. 'Full levelling' adjusts the values of an input channel by adding a correction defined in an error channel. In a second step, an iterative levelling algorithm was again applied, this time simultaneously to all profiles from both platforms. In
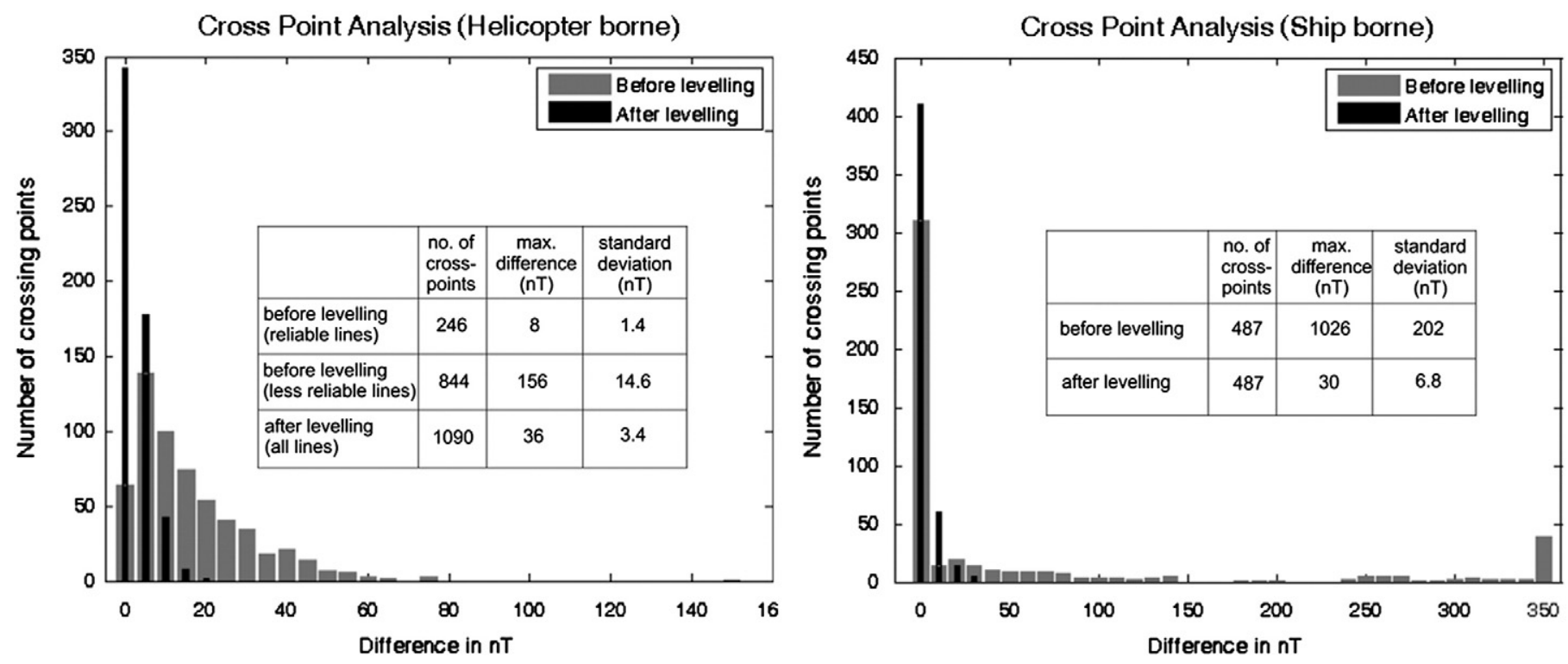

Fig. 4. Results of the cross-point analysis for the helicopter-borne and ship-borne survey lines before and after levelling. 

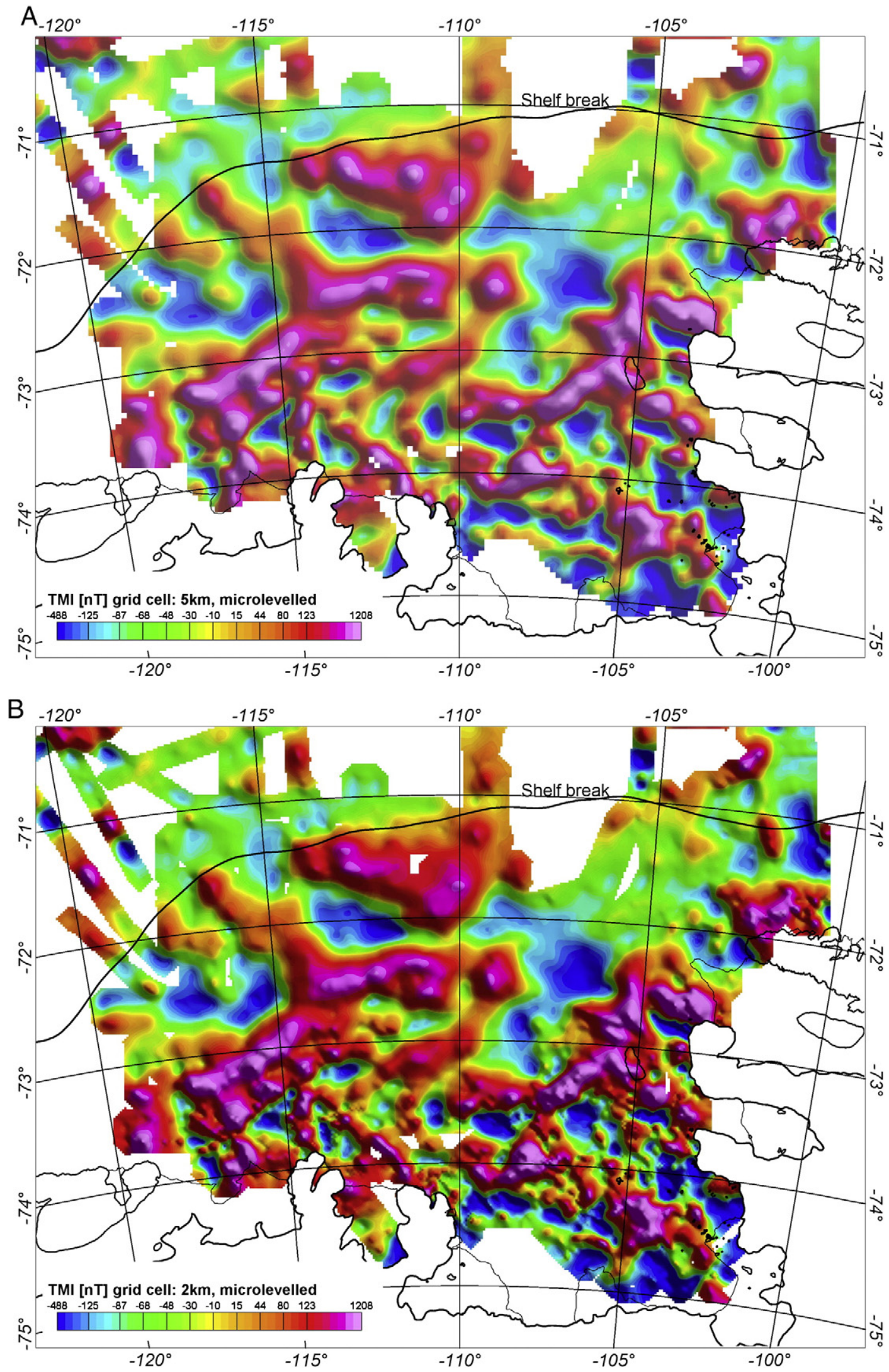

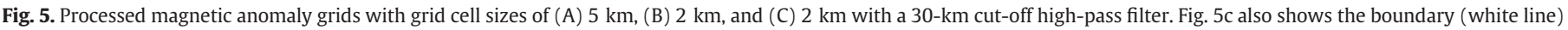

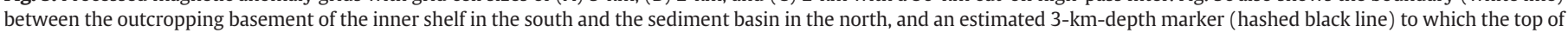
basement dips northward from this boundary. 


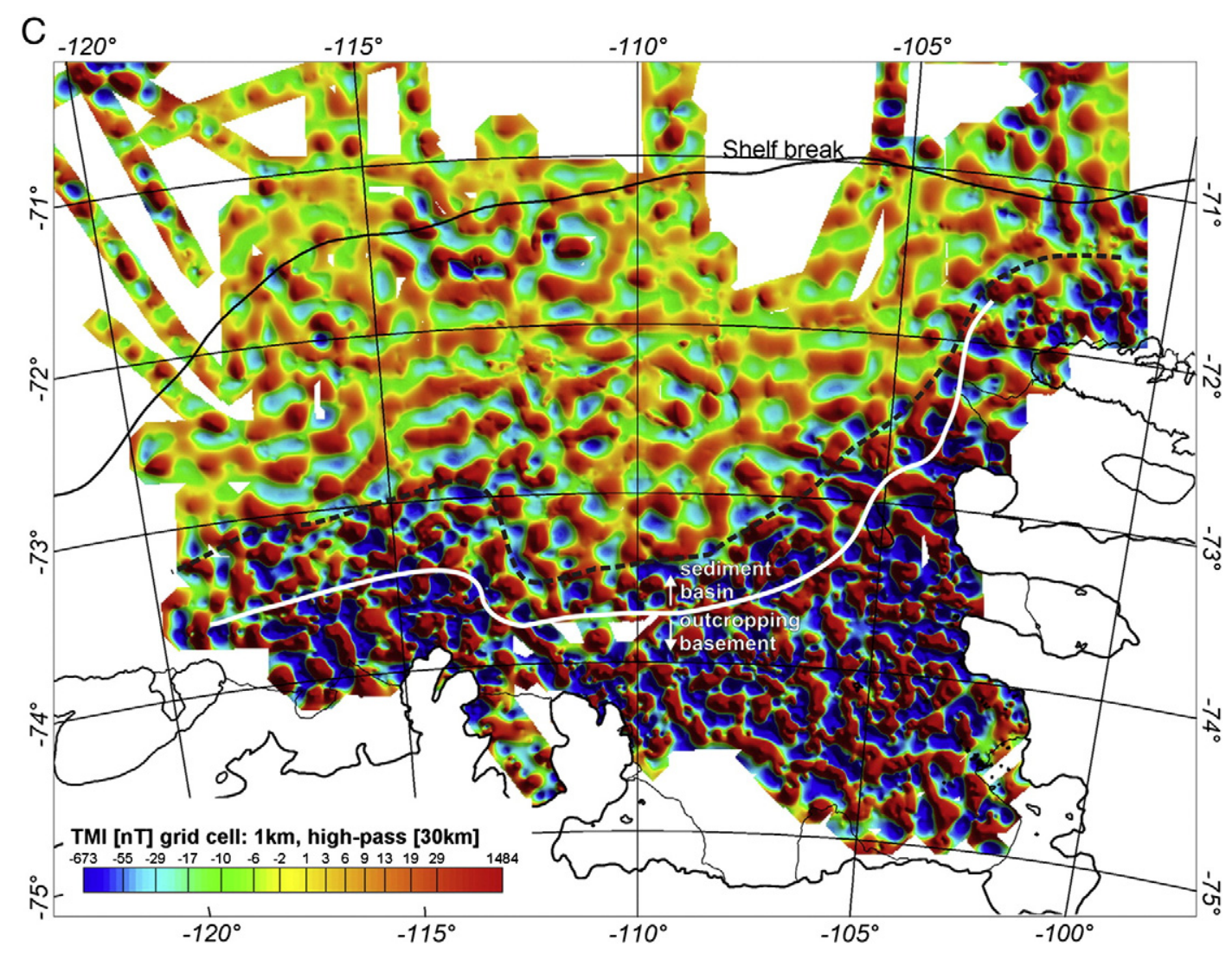

Fig. 5 (continued).

this step, we levelled the ship-borne data into the levelled framework of helicopter data after splitting the ship-borne data into straight segments and generating an intersection table with points of ship-borne data crossing helicopter survey lines. Intersection points within the ship-borne dataset were ignored. The cross-point histograms and tables (Fig. 4) show the large reduction in intersection misfits brought about by the levelling. It is noteworthy that the levelling process removes the large errors ( $350 \mathrm{nT})$ at ship-line cross-points in south-eastern Pine Island Bay, which are a long distance from the nearest compensation loop.

Gridding and micro-levelling: Particular care was taken in gridding the data because of the irregular line spacing and orientation. We applied a minimum curvature approach between less sampled areas and those areas with good coverage. Initially, a coarse grid with a large grid cell size is used. Nodes represent either the real data, which is found within a specific radius, or an average of all data points of the grid. Iteratively, the grid is adjusted to the real data nearest to the grid nodes. If an acceptable misfit between real data and coarse grid node is achieved, the cell size is divided by two and the procedure starts again. The gridded data still show some noise resulting from residual levelling and gridding errors. Although these errors are small in comparison to the measured anomalies, they account considerably for noise in further processing. Removing these errors by the application of a low-pass filter to smooth derivative grids is a process known as micro-levelling (Ferraccioli et al., 1998; Green, 1983). As the screening of the line data indicated, the shelf is partitioned into two magnetic anomaly domains characterised by different wavelengths. We found that micro-levelled grids of 5 and $2 \mathrm{~km}$ cell size best represent both domains with a minimum of artefacts
(Fig. 5A,B). A further decrease of the cell size to $1 \mathrm{~km}$ in combination with a $30-\mathrm{km}$ high-pass filter (Fig. $5 \mathrm{C}$ ) shows clearly the wave-field distinction between the inner shelf domain and the middle to outer shelf but also creates numerous artificial anomalies.

Further analytical field analysis: We applied a wide spectrum of standard wave-field processing methods to the grid in order to constrain directional trends and the shapes and edges of magnetic anomaly units. These methods included the calculation and application of (1) horizontal, vertical and tilt derivatives, (2) upward field continuations, (3) high-pass filters, (4) pseudo gravity and (5) analytical signal. At moderate wavelengths, these methods serve to highlight the magnetic bodies and tectonic lineation trends that can be coarsely interpreted from the regular anomaly grids. High-pass filtering, in particular, much more readily delineates the boundary zone between outcropping basement of the inner shelf and the sedimentary cover of the middle and outer shelf (Fig. 5C).

\section{Depth estimates}

In addition to standard power spectra analyses for estimating the depths of magnetic anomaly sources, we applied the Euler deconvolution method to the grid in an attempt to better delineate the spatial distribution and extent of the tops and edges of source bodies. We used the approach of Thomson (1982) and Reid et al. (1990) in which the depth solution is related to a chosen structural index SI ( 0 for a planar contact, 1 for a dike or sill, 2 for a vertical pipe, 3 for a sphere). A square window is defined within the grid, which contains at least $3 \times 3$ grid cells. For each grid cell, the deconvolution is calculated. Hence, a $3 \times 3$ cell window results in 9 equations, which are solved via a least-squares inversion. The 

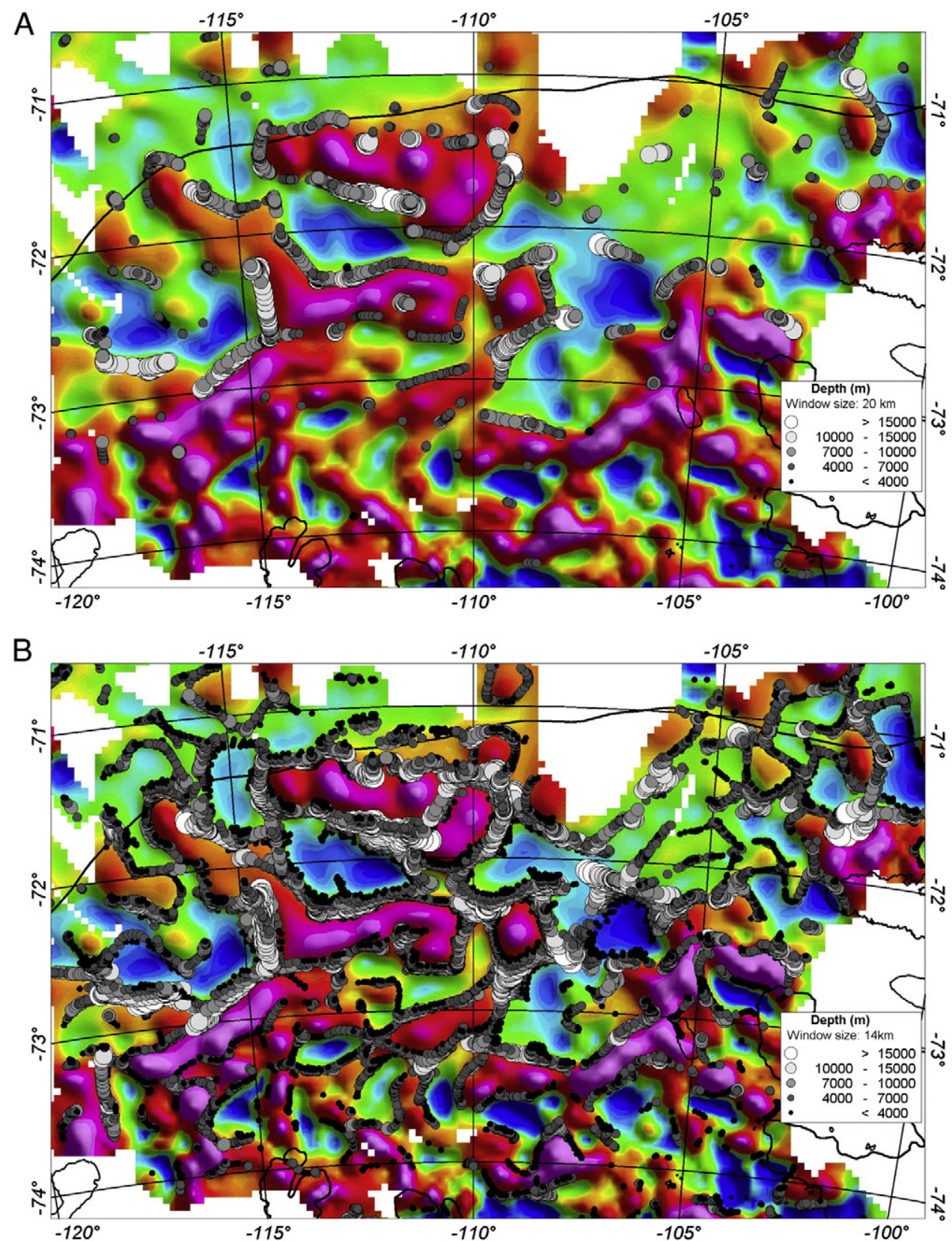

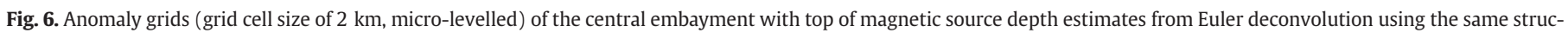
tural index of $S I=0$, but different window sizes of (A) $20 \mathrm{~km}$ and (B) $14 \mathrm{~km}$.

window is then shifted across the grid and the same procedure is applied. It is obvious that the solution is dependent on the chosen window size. If the window size is so large that neighbouring anomalies intrude into it, the inversion can fail and its solutions are rejected. This is the case for distinct anomalies on the inner shelf in the south (Fig. 6A). On the other hand, if a window size is too small, then anomalies from deep-seated sources may not be adequately represented in the inversion, interfering with the solutions for shallower sources and resulting in artificially shallow source solutions. Fig. 6B shows that smaller window sizes generate more solutions and that long-wavelength anomalies yield shallower depth solutions than when a larger window is used.

Our two examples of Euler deconvolution solutions use different window sizes of 14 and $20 \mathrm{~km}$ but the same structural index (Fig. 6). The solutions provide estimates of a dense distribution of source tops at depths below $7 \mathrm{~km}$ over the middle to outer shelf, while further south, below the inner shelf, source tops are typically located at depths shallower than $7 \mathrm{~km}$.

\section{Tectonic lineaments and 2D modelling}

One of the most striking observations in the magnetic anomaly grid is the domination of the inner shelf by relatively short-wavelength anomalies and the middle and outer shelf by middle to long wavelength anomalies (Fig. 5A,B). The boundary between the two domains is abrupt and clearly shown in the high-pass filtered wavefield (Fig. 5C). This boundary is the northern limit of a coastal and inner shelf domain in which basement crops out or exists in shallow subcrop, as suggested by the rugged topography (Fig. 1). It can be assumed that most of this basement is composed of crystalline rocks similar in type to the granitoids and porphyritic dykes observed from coastal and island outcrops of the embayment (e.g. Kipf et al., 2012; Pankhurst et al., 1993). Conversely, the longer wavelength signals over the middle and outer shelf are consistent with the presence of a thick drape of sediments overlying the basement (Lowe and Anderson, 2002; Weigelt et al., 2009). Depth estimates from Euler deconvolution help identify a boundary zone 


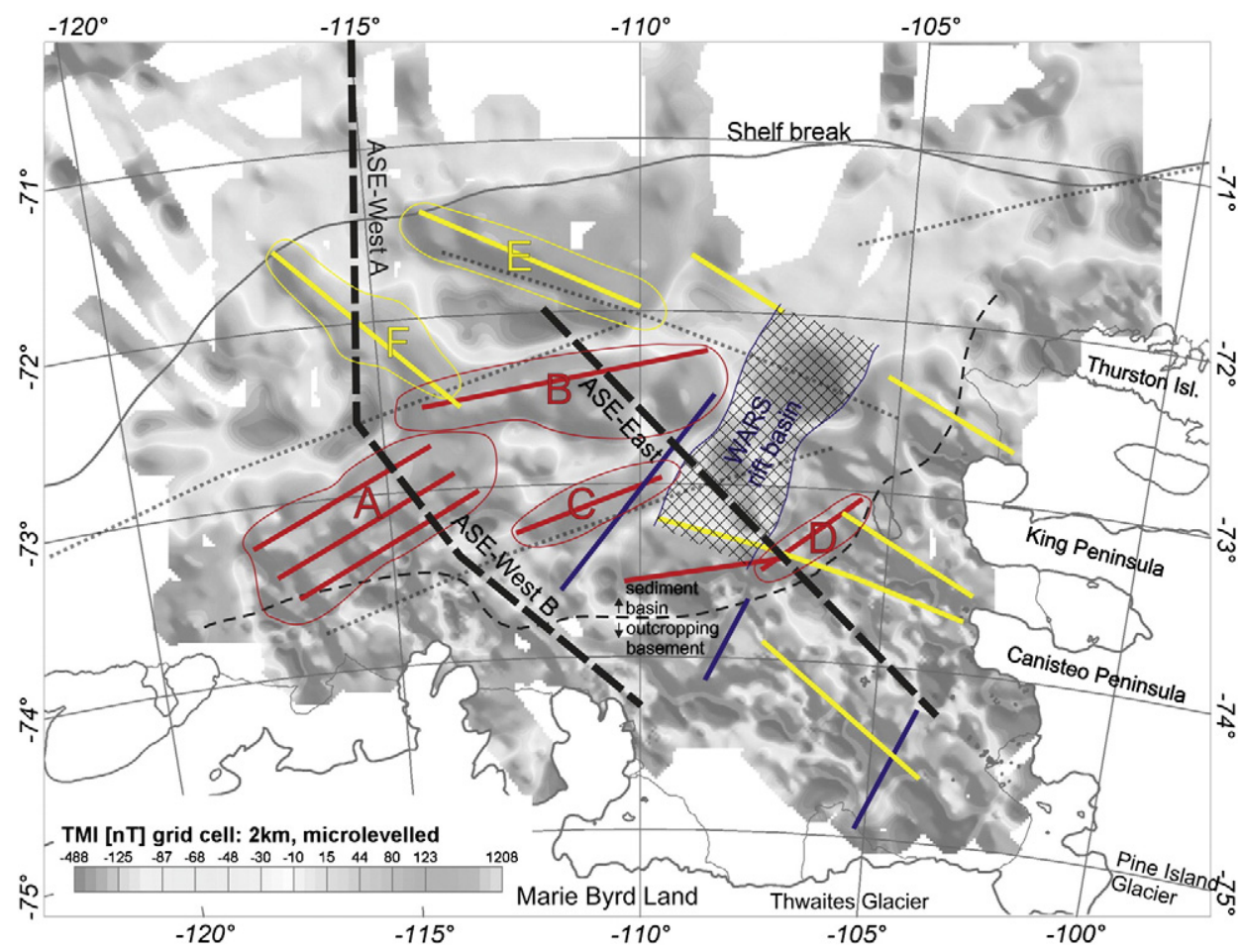

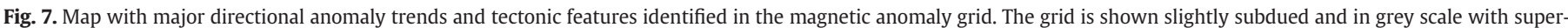

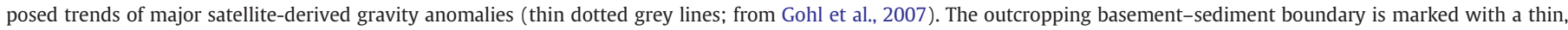

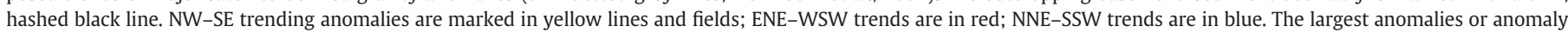

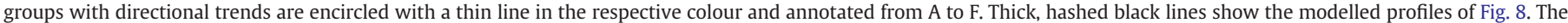
WARS rift basin is interpreted as a branch of the West Antarctic Rift System.

across which the basement drops downwards to the north to about $3 \mathrm{~km}$ depth (Fig. 5C), which is consistent with observations from seismic data across this boundary (Graham et al., 2009; Lowe and Anderson, 2002; Uenzelmann-Neben et al., 2007; Weigelt et al., 2009).

One of the objectives of the magnetic surveys was to identify crustal features for delineating tectonic events in the history of the crustal formation in the Amundsen Sea Embayment (Fig. 7). The middle and outer shelf show fundamentally different preferential anomaly strikes. While a major set of long-wavelength anomalies strike WSW-ENE along the middle shelf, the outer shelf west of $107^{\circ} \mathrm{W}$ exhibits mainly NW-SE striking anomalies which may continue on the inner shelf of the eastern embayment. A third directional trend is observed for positive anomalies on the inner and middle shelf striking NNE-SSW. These are less pronounced but seem to border a broad magnetic zone of low amplitude negative anomalies on the middle shelf at $106-109^{\circ} \mathrm{W}$.

We selected two 2D modelling transects crossing the Amundsen Sea Embayment shelf from north to south and NW to SE across the major observed magnetic anomaly lineaments and proposed source bodies (Fig. 7). The data along the transects were taken from the magnetic anomaly grid at $5 \mathrm{~km}$ cell size. Encom ModelVision ${ }^{\mathrm{TM}}$ was used as modelling software. The depth estimates from Euler deconvolution solutions provided some constraints for the parameterisation of these magnetic susceptibility models. Other constraints on crustal properties, such as crustal thickness, sediment thickness and the approximate locations of mafic (high density, high susceptibility) bodies, were implemented from seismic reflection data (Weigelt et al., 2009), a deep crustal seismic refraction model and a gravity anomaly inversion of the Amundsen Sea shelf region with crustal thicknesses of 20-25 km (Gohl et al., 2007). Water depths were taken from the bathymetry compilation of Nitsche et al. (2007).

We chose a modelling procedure in which we parameterized the model starting with thick layers and large bodies from the lower crust for long-wavelength signals and moving on to small-size layers and bodies of the upper crust to generate short-wavelength signals. The responses were iteratively calculated for a range of susceptibilities and body sizes such that the root-mean-square (rms) misfit between observed and calculated total intensities could be minimised. Due to the different wave-field characteristics of transects ASE-West A, ASE-West B and ASE-East, each model was treated independently of the others. Although various studies show that the ranges of susceptibilities of individual rock types can span several orders of magnitude, it is possible to distinguish domains of sedimentary, felsic and mafic composition on the basis of susceptibilities. Most published susceptibilities of intrusive felsic rocks range from 0.0001 to $0.02 \mathrm{SI}$ unit (average $0.0012 \mathrm{SI}$ ), while those of intrusive rocks of mafic composition have values of 0.0001 to 0.13 SI (average 0.012 SI) (e.g. Sanger and Glen, 2003). We applied a constant susceptibility of 0.000005 SI for sediments and of 0.001 SI for the bulk of the continental crust in all models and started modelling with the average values of intrusive bodies by Sanger and Glen (2003). By adjusting the susceptibilities of these bodies, we stayed within the above given ranges.

The model transect ASE-West A (Fig. 8A) covers the continental slope and the outer shelf and includes two high-susceptibility bodies embedded into the upper crust of the continental rise. Much of the upper surface of the large high-susceptibility body 3 beneath the

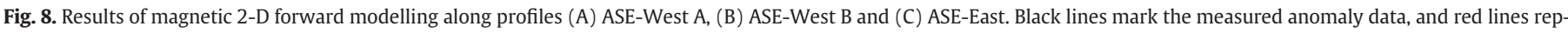

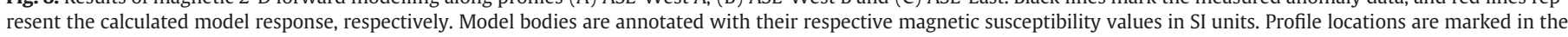
map of Fig. 7. 

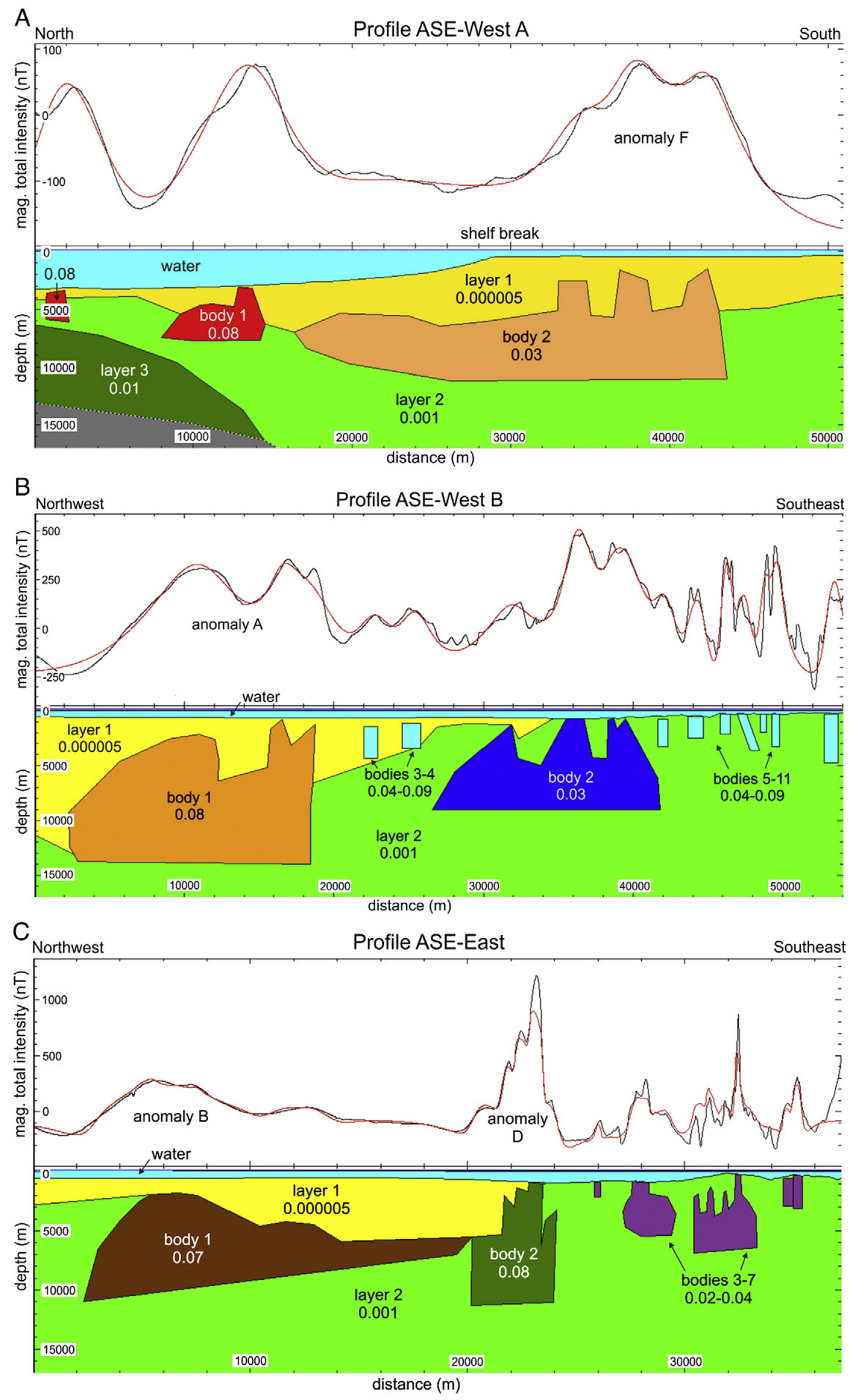
slope and outer shelf is located beneath $5 \mathrm{~km}$ depth, with shallower peaks at 2-3 km depth, producing the long-wavelength high with superposed short-wavelength fluctuations seen in the data. Similar high-susceptibility bodies were required to fit the anomalies of the middle and inner shelf model transects ASE-West B (Fig. 8B) and ASE-East (Fig. 8C). In both models, we inserted shallow, small-sized bodies of high susceptibilities to fit the shortest wavelength anomalies. On the inner shelf, where basement crops out, we topped most of the source bodies at the seafloor.

\section{Superposed tectonic events}

The modelled properties of the dominant ENE-WSW trending magnetic anomalies A, B, C and D (Fig. 7) indicate that they are caused by major elongated and deep-seated features of predominantly mafic composition. They parallel the initial spreading centre's azimuth between Chatham Rise and West Antarctica and can thus be related to rift processes occurring before breakup as early as $100 \mathrm{Ma}$ and during breakup between 90 and 85 Ma (Eagles et al., 2004a; Larter et al., 2002; Wobbe et al., 2012). With their seaward-dipping outer edges, bodies of anomalies A and B might be interpreted as thick wedges of basaltic lava and mafic intrusions of the kind known from volcanic extended continental margins such as the Vøring margin or Afar Rift (Planke and Eldholm, 1994; Wolfenden et al., 2005). The body modelled for anomaly A reaches near the seafloor at its southern limit which correlates with the steep northern flank of the inner DotsonGetz Trough (Graham et al., 2009; Larter et al., 2009). The trough coming from the Getz B Ice Shelf strikes nearly in east-west direction on the inner shelf before merging with the outflow troughs originating from the Getz A and Dotson Ice Shelves and turning northwards on the middle shelf and to the northwest on the outer shelf (Fig. 1). We suggest that this intrusive body is more resistant to pre-glacial and glacial erosion and caused an east to northeastward deviation of grounded ice streams from the eastern Getz Glacier.

The NW-SE trending set of magnetic anomalies (including $\mathrm{E}$ and $\mathrm{F}$ of Fig. 7) is parallel to the so-called Peacock Gravity Anomaly northwest of Peacock Sound (Eagles et al., 2004a; Larter et al., 2002) which has been modelled with an underlying high-density body (Gohl et al., 2007). It is interpreted as a magmatic zone, which interferes with the ENE-WSW trending rift structure (causing anomalies A to D). Modelling along transect ASE-West A indicates that the magnetic anomalies in this zone are caused by elongated bodies of similar depth, dimension and susceptibility as those causing the ENE-WSW trending anomalies. Consistent with the plate tectonic process described for the Bellingshausen Plate (Eagles et al., 2004a,b; Wobbe et al., 2012) we infer that these features represent mafic intrusions emplaced when the southern Bellingshausen Plate boundary was active between 80 and $61 \mathrm{Ma}$, giving rise to a distributed pattern of compressional, extensional and translateral movements at various stages of the activity of this boundary. The location of these magmatic units over a long time period in a very wide continent-ocean transition zone (Wobbe et al., 2012) suggests the Amundsen Sea Embayment may be the product of a long-lived zone of distributed crustal deformation, and that it may host multiple failed rifts and rift accommodation zones.

The third set of magnetic anomaly lineaments runs NNE-SSW, is rather subtle in amplitude, and more spatially limited than the other anomaly sets (Fig. 7). The broad magnetic anomaly low indicates the presence of a sedimentary sub-basin within the middle shelf. The margins of this low are asymmetrical; its southeastern margin is characterised by greater amplitudes and shorter wavelength anomalies than its northwestern margin. The basin, therefore, might be interpreted as having a half-graben geometry, with a bounding basement-involved normal fault zone on its southeastern edge, and a downthrown floor characterised by broad flexure northwestward away from the fault zone. The Palaeogene plate tectonic model of
Müller et al. (2007) predicts that a crustal boundary with this orientation would have responded to West Antarctica-East Antarctica relative motion along the WARS in right-lateral strike-slip motion. They suggest that this boundary extended from the Bentley Subglacial Trough and Byrd Subglacial Basin across western Ellsworth Land and the Thurston Island block, where it continues into the area of the dominant north-trending gravity anomaly lineaments of the Bellingshausen Sea. More consistent with the interpretation of a NNE-trending basin, however, the alternative plate tectonic model of Cande et al. (2000) predicts a strongly oblique right-lateral extension. In any case, the orientation of the identified sub-basin on the eastern ASE shelf (annotated as 'WARS rift basin' in Fig. 7) infers that it may be related to eastern WARS motion, possibly active as early as $55 \mathrm{Ma}$ and lasting until at least $30 \mathrm{Ma}$ before the zone of translateral deformation migrated or jumped eastward to join the triple junction at the spreading ridge colliding with the convergent margin of the southern Antarctic Peninsula as postulated by Müller et al. (2007). Somewhat more speculative, but not unrealistic, is a correlation of the sub-basin with the dextral transtensional strain in western Marie Byrd Land observed by Siddoway (2008), who interprets this strain as an expression of an early WARS activity in the Late Cretaceous.

The shallow, small-sized bodies of very high susceptibilities between 0.02 and 0.09 SI unit on the inner shelf (Fig. 8b,c), are interpreted to be caused by a mafic dyke field related to the Cenozoic volcanic province of eastern Marie Byrd Land and western Ellsworth Land (e.g. LeMasurier, 1990; Paulsen and Wilson, 2010). Due to the presence of the nearby volcanic Hudson Mountains, one might expect volcanic, $\sim 5 \mathrm{~km}$ radius cone-like features on the shelf as well, but the line spacing of the survey does not allow for the unequivocal identification or clear resolution of such features.

\section{Conclusions}

Newly acquired magnetic datasets from helicopter-borne and ship-borne surveys in 2006 and 2010 were used to generate levelled anomaly grids from the shelf of the Amundsen Sea Embayment. We applied grid processing, Euler deconvolution and 2D modelling for the analysis of magnetic anomaly patterns, identification of structural lineaments, and characterisation of magnetic source bodies.

The magnetic anomaly grid clearly outlines the boundary zone between the inner shelf where basement rocks crop out and a more thickly-sedimented middle to outer shelf. This sedimentation can be related to a long history of distributed extension inferred from the regional plate tectonic setting and from the presence of distinct zones of anomaly patterns and lineaments that can be associated with at least three tectonic phases in that history.

The first of these phases was the establishment of magmatic emplacement zones during Cretaceous New Zealand-Antarctic rifting and breakup (100-85 Ma). The second phase involved further magmatism in a distributed plate boundary zone between the Bellingshausen and Antarctic plates (80-61 Ma). Finally, the West Antarctic Rift System may have caused further extension in the region at later times (55-30 Ma?), focussed within a possible half-graben basin system bounded by NNE-SSW trending tectonic lineaments. Mafic dykes cross the inner shelf of the embayment and Pine Island Bay and may be associated with Cenozoic volcanism observed on land. They possibly relate to activities of one of the eastern branches of the West Antarctic Rift System.

Our magnetic data and the analysis show for the first time an identification of at least three sets of superposed tectonic lineaments in the Amundsen Sea Embayment shelf. The correlation of this observation to plate tectonic motion and associated magmatic emplacement in the West Antarctic realm suggests that the wide shelf of the Amundsen Sea Embayment may be the product of a long-lived zone 
of distributed crustal deformation, and that it may host multiple failed rifts and rift accommodation zones.

By an example of a modelled intrusive body, this study also shows that such emplacement of resistive material acted as an obstacle for past ice flows across the inner shelf.

\section{Acknowledgements}

Many thanks to the ship crews, the helicopter pilots of Heli-Service $\mathrm{GmbH}$ and the geophysical teams for their support of acquiring the magnetic data during RV Polarstern expeditions ANT-XXIII/4 (2006) and ANT-XXVI/3 (2010). We, in particular, thank Volker Leinweber, Sonja Suckro and Christina Mayr for their engagement in the helicoptermagnetic team of 2006. The collaboration with Prof. B. Tezkan of the University of Cologne in co-supervising A. Denk's Diploma/MSc thesis, of which parts contributed to this paper, is gratefully acknowledged. This project is entirely supported by institutional funds of the Alfred Wegener Institute.

\section{References}

Cande, S.C., Stock, J.M., Müller, R.D., Ishihara, T., 2000. Cenozoic motion between East and West Antarctica. Nature 404, 145-150.

Dalziel, I.W.D., 2006. On the extent of the active West Antarctic rift system. In: Siddoway, C.S., Ricci, C.A. (Eds.), Proceedings of Workshop on Frontiers and Opportunities in Antarctic Geosciences. : Terra Antarctica Reports, 12. Terra Antarctica Publications, Siena, Italy, pp. 193-202.

Dalziel, I.W.D., Elliot, D.H., 1982. West Antarctica: problem child of Gondwanaland Tectonics 1, 3-19.

Eagles, G., Gohl, K., Larter, R.D., 2004a. High-resolution animated tectonic reconstruction of the South Pacific and West Antarctic margin. Geochemistry, Geophysics, Geosystems 5. http://dx.doi.org/10.1029/2003GC000657.

Eagles, G., Gohl, K., Larter, R.D., 2004b. Life of the Bellingshausen plate. Geophysical Research Letters 31, L07603. http://dx.doi.org/10.1029/2003GL019127.

Eagles, G., Larter, R.D., Gohl, K., Vaughan, A.P.M., 2009. Antarctic Rift System in the Antarctic Peninsula. Geophysical Research Letters 36, L21305. http://dx.doi.org/ 10.1029/2009GL040721.

Ferraccioli, F., Gambetta, M., Bozzo, E., 1998. Microlevelling procedures applied to regiona aeromagnetic data: an example from the Transantarctic Mountains Antarctica. Geophysical Prospecting 46, 177.

Ferraccioli, F., Jordan, T.A., Vaughan, D.G., Holt, J., James, M., Corr, H., Blankenship, D.D. Fairhead, J.D., Diehl, T.M., 2007. New aerogeophysical survey targets the extent of the West Antarctic Rift System over Ellsworth Land. In: Cooper, A.K., Raymond, C.R. (Eds.), Proceedings of the 10th Int. Symposium of Antarctic Earth Sciences: USGS Open-File Report 2007-1047, 113. Extended Abstract.

Gohl, K., 2011. Basement tectonics and ice sheet dynamics in the Amundsen Sea Embayment, West Antarctica. Palaeogeography, Palaeoclimatology, Palaeoecology. http://dx.doi.org/10.1016/j.palaeo.2011.02.022.

Gohl, K., Nitsche, F., Miller, H., 1997. Seismic and gravity data reveal Tertiary interplate subduction in the Bellingshausen Sea, southeast Pacific. Geology 25, 371-374.

Gohl, K., Teterin, D., Eagles, G., Netzeband, G., Grobys, J., Parsiegla, N., Schlüter, P. Leinweber, V., Larter, R.D., Uenzelmann-Neben, G., Udintsev, G.B., 2007. Geophysical survey reveals tectonic structures in the Amundsen Sea Embayment, West Antarctica. In: Cooper, A.K., Raymond, C.R., et al. (Eds.), Proceedings of the 10th Int. Symposium of Antarctic Earth Sciences: USGS Open-File Report 2007-1047. http://dx.doi.org/10.3133/of2007-1047.srp047.

Graham, A.G.C., Larter, R.D., Gohl, K., Hillenbrand, C.-D., Smith, J.A., Kuhn, G., 2009 Bedform signature of a West Antarctic palaeo-ice stream reveals a multitemporal record of flow and substrate control. Quaternary Science Reviews 28, 2774-2793. http://dx.doi.org/10.1016/j.quascirev.2009.07.003.

Green, A., 1983. A comparison of adjustment procedures for leveling aeromagnetic survey data. Geophysics 48, 745-753.

Grunow, A.M. Kent, D.V. Dalziel, I.W.D. 1991. New paleomagnetic data from Thurston Island: implications for the tectonics of West Antarctica and Weddell Sea opening. Journal of Geophysical Research 96 (B11), 17935-17954.

Jordan, T.A., Ferraccioli, F., Vaughan, D.G., Holt, J.W., Corr, H., Blankenship, D.D., Diehl T.M., 2010. Aerogravity evidence for major crustal thinning under the Pine Island Glacier region (West Antarctica). Geological Society of America Bulletin 122, 714-726. http://dx.doi.org/10.1130/B26417.1

Kipf, A., Mortimer, N., Werner, R., Gohl, K., van den Bogaard, P., Hauff, F., Hoernle, K. 2012. Granitoids and dykes of the Pine Island Bay region, West Antarctica. Antarctic Science. http://dx.doi.org/10.1017/S0954102012000259.

König, M., 2006. Processing of shipborne magnetometer data and revision of the timing and geometry of the Mesozoic break-up of Gondwana. PhD thesis, University of Bremen, Reports on Polar and Marine Research, no. 525, 137 pp.

Larter, R.D., Cunningham, A.P., Barker, P.F., Gohl, K., Nitsche, F.O., 2002. Tectonic evolution of the Pacific margin of Antarctica - 1. Late Cretaceous tectonic reconstructions.
Journal of Geophysical Research 107 (B12), 2345. http://dx.doi.org/10.1029/ 2000JB000052.

Larter, R.D., Graham, A.G.C., Gohl, K., Kuhn, G., Hillenbrand, C.-D., Smith, J.A., Deen, T.J., Livermore, R., Schenke, H.-W., 2009. Subglacial bedforms reveal complex basal regime in a zone of paleo-ice stream convergence, Amundsen Sea Embayment, West Antarctica. Geology 37, 411-414. http://dx.doi.org/10.1130/G25505A.

LeMasurier, W.E., 1990. Late Cenozoic volcanism on the Antarctic plate: an overview. In: LeMasurier, W.E., Thomson, J.W. (Eds.), Volcanoes of the Antarctic Plate and Southern Oceans: American Geophysical Union Antarctic Research Series, 48, pp. $1-17$.

Lowe, A.L., Anderson, J.B., 2002. Reconstruction of the West Antarctic ice sheet in Pine Island Bay during the Last Glacial Maximum and its subsequent retreat history. Quaternary Science Reviews 21, 1879-1897.

McFadden, R.R., Teyssier, C., Siddoway, C.S., Whitney, D.L., Fanning, C.M., 2010. Oblique dilation, melt transfer, and gneiss dome emplacement oblique dilation, melt transfer, and gneiss dome emplacement. Geology 38, 375-378. http://dx.doi.org/10.1130/ G30493.1.

Müller, R.D., Gohl, K., Cande, S.C., Goncharov, A., Golynsky, A.V., 2007. Eocene to Miocene geometry of the West Antarctic rift system. Australian Journal of Earth Sciences 54, 1033-1045. http://dx.doi.org/10.1080/08120090701615691.

Nitsche, F.O., Jacobs, S., Larter, R.D., Gohl, K., 2007. Bathymetry of the Amundsen Sea continental shelf: implications for geology, oceanography, and glaciology. Geochemistry, Geophysics, Geosystems 8, Q10009. http://dx.doi.org/10.1029/ 2007 GC001694.

Nogi, Y., Kaminuma, K., 1999. Measurements of vector magnetic anomalies on board the icebreaker Shirase and the magnetization of the ship. Annali di Geofisica 42, $161-170$.

Pankhurst, R.J., Millar, I.L., Grunow, A.M., Storey, B.C., 1993. The pre-Cenozoic magmatic history of the Thurston Island crustal block, West Antarctica. Journal of Geophysical Research 98 (B7), 11835-11849. http://dx.doi.org/10.1029/93JB01157.

Paulsen, T.S., Wilson, T.J., 2010. Evolution of Neogene volcanism and stress patterns in the glaciated West Antarctic Rift, Marie Byrd Land, Antarctica. Journal of the Geological Society 167, 401-416. http://dx.doi.org/10.1144/0016-76492009-044.

Planke, S., Eldholm, O., 1994. Seismic response and construction of seaward dipping wedges of flood basalts: Vøring volcanic margin. Journal of Geophysical Research 99, 9263-9278.

Pollard, D., DeConto, R.M., 2009. Modelling West Antarctic ice sheet growth and collapse through the past five million years. Nature 458, 329-333. http://dx.doi.org/ 10.1038/nature07809.

Pritchard, H.D., Arthern, R.J., Vaughan, D.G., Edwards, L.A., 2009. Extensive dynamic thinning on the margins of the Greenland and Antarctic ice sheets. Nature 461, 971-975. http://dx.doi.org/10.1038/nature08471.

Reid, A., Allsop, J., Granser, H., Millett, A., Somerton, I., 1990. Magnetic interpretation in three dimensions using Euler deconvolution. Geophysics 55, 80-91.

Rignot, E.J., Bamber, J.L., van den Broeke, M.R., Davis, C., Li, Y., van de Berg, W., van Meijgaard, E., 2008. Recent Antarctic ice mass loss from radar interferometry and regional climate modelling. Nature Geoscience 1, 106-110. http://dx.doi.org/ 10.1038/ngeo102.

Sanger, E.A., Glen, J.M.G., 2003. Density and magnetic susceptibility values for rocks in the Talkeetna Mountains and adjacent region, South-Central Alaska. U.S. Geological Survey Open-File Report 03-268.

Siddoway, C.S., 2008. Tectonics of the West Antarctic Rift System: new light on the history and dynamics of distributed intracontinental extension. In: Cooper, A.K., Barrett, P.J., Stagg, H., Storey, B., Stump, E., Wise, W. (Eds.), Antarctica: A Keystone in a Changing World. : Proceedings of the 10th International Symposium on Antarctic Earth Sciences. The National Academies Press, Washington, DC, pp. 91-114. http://dx.doi.org/ 10.3133/of2007-1047.kp09.

Storey, B.C., 1991. The crustal blocks of West Antarctica within Gondwana: reconstruction and break-up model. In: Thomson, M.R.A., Crane, J.A., Thomson, J.W. (Eds.), Geological Evolution of Antarctica. Cambridge University Press, Cambridge.

Thomson, D.T., 1982. EULDPH: a new technique for making computer-assisted depth estimates from magnetic data. Geophysics 47, 31-37.

Uenzelmann-Neben, G., Gohl, K., Larter, R.D., Schlüter, P., 2007. Differences in ice retreat across Pine Island Bay, West Antarctica, since the Last Glacial Maximum: indications from multichannel seismic reflection data. In: Cooper, A.K., Raymond, C.R., et al. (Eds.), Proceedings of the 10th ISAES: USGS Open-File Report 2007-1047. http://dx.doi.org/10.3133/of2007-1047.srp084.

Vaughan, D.G., Corr, H.F.J., Ferraccioli, F., Frearson, N., O'Hare, A., Mach, D., Holt, J.W., Blankenship, D.D., Morse, D., Young, D.A., 2006. New boundary conditions for the West Antarctic ice sheet: subglacial topography beneath Pine Island Glacier. Geophysical Research Letters 33, L09501.

Weigelt, E., Gohl, K., Uenzelmann-Neben, G., Larter, R.D., 2009. Late Cenozoic ice sheet cyclicity in the western Amundsen Sea Embayment - evidence from seismic records. Global and Planetary Change 69, 162-169. http://dx.doi.org/10.1016/ j.gloplacha.2009.07.004

Wobbe, F., Gohl, K., Chambord, A., Sutherland, R., 2012. Structure and breakup history of the rifted margin of West Antarctica in relation to Cretaceous separation from Zealandia and Bellingshausen plate motion. Geochemistry, Geophysics, Geosystems 13, Q04W12. http://dx.doi.org/10.1029/2011GC003742.

Wolfenden, E., Ebinger, C., Yirgu, G., Renne, P.R., Kelley, S.P., 2005. Evolution of a volcanic rifted margin: Southern Red Sea, Ethiopia. Geological Society of America Bulletin 117, 846-864. http://dx.doi.org/10.1130/B25516.1. 